\title{
Social Olfaction: A Review of the Ontogeny of Olfactory Influences on Vertebrate Behavior
}

\author{
MARYLOU CHEAL ${ }^{1}$ \\ Department of Zoology, The University of Michigan
}

\begin{abstract}
Research on the postnatal development of behavior involving olfaction is reviewed. Included are investigations of olfactory responses of human neonates and young children, the development of preferences in various mammals, the ontogeny of the fright reaction in fish and amphibia, and the attraction of maternal odors for small mammals. The effects of early exposure and conditioning to olfactory stimuli on adult behavior in mammals and fish are reported including a survey of the status of the olfactory hypothesis in fish migration. Deprivation experiments suggest disruption of later behavior. Limitations of the present knowledge and directions for future research are presented.
\end{abstract}

An increased interest in the role of olfaction in animal behavior is reflected by several recent reviews (Bardach and Todd, 1970; Bronson, 1971; Cheal and Sprott, 1971; E. O. Wilson, 1972; Johnson, 1973; Schultz and Tapp, 1973). However, none of these reviews has emphasized the behavioral evidence pertinent to the development of the influence of olfaction. This paper will review research on the importance of pheromones and other odors to neonates, the dependence of the sense of olfaction on chemical influences of early life, and the effects of early odor experience on adult behavior in mammals, fish, and amphibia. Relevant research in reptiles and birds, to my knowledge, has not been done. The term pheromone refers to chemicals liberated by one animal that result in a relatively specific modification of the development, reproduction, or behavior of a recipient animal (Bronson and Dezell, 1968; Gleason and Reynierse, 1969; Bruce, 1970; Cheal and Sprott, 1971; Birch, 1974).

1The author wishes to thank Dr. Richard L. Sprott for his critical reading of an earlier draft of the manuscript. Supported by U.S. Public Health Service Grant NS07072 to Dr. Bruce Oakley. The author's present address: Department of Oral Biology, School of Dentistry, The University of Michigan, Ann Arbor, Michigan 48104. 


\section{HUMANS}

Research in human neonates has demonstrated the ability of newborn infants to respond to olfactory stimuli (Bronshtein, Antonova, Kamenetskaya, Luppova, and Sytova, 1960; Engen, Lipsitt, and Kaye, 1963). Researchers have also used human neonates as psychophysical observers to contribute information on basic sensory processes (Rovee, 1969, 1972). Bronshtein et al. (1960) found that the sucking response in human infants would change upon presentation of sensory stimuli. Sucking ceased or decreased in frequency when anise, iodoform, or peppermint were presented in about the same percentage of children as was seen in rabbits, kittens, and puppies. Engen et al. (1963) measured leg withdrawal, general body movement, respiration, and heart rate changes upon presentation of olfactory stimuli to infants from 32 to $68 \mathrm{hr}$ of age. Larger responses were elicited with acetic acid or asafetida than with phenylethyl alcohol or anise. A decrement in the frequency of response was seen in repeated trials of asafetida or anise but not with acetic acid or phenylethyl alcohol. Two explanatory hypotheses were proposed. The response decrement could be due to habituation to the novel stimulus or to sensory adaptation. To test these hypotheses a mixture of two stimulants was presented to infants until a response was no longer elicited (Engen and Lipsitt, 1965). When one component of the mixture was then presented the response recovered, suggesting that the habituation hypothesis was correct. Although another study of 32 infants was designed to investigate the stability of responding with increasing age using single concentrations of odors which the authors considered "purely olfactory" and not "trigeminal irritants," the data primarily reflected the high variability typical of the newborn (Self, Horowitz, and Paden, 1972). When tested with increasing concentrations of asafetida, infants demonstrated increasing sensitivity over the first 4 days of life (Lipsitt, Engen, and Kaye, 1963). The evidence suggests that the human response to odors, present at birth, increases in sensitivity during the first days of life. Children from 4 to $7 \mathrm{yr}$ of age discriminated the intensity of odors such as butyric acid and safrole similarly to adults (Engen, 1974). However, when asked if the substance smelled "pretty," the younger children generally found unpleasant odors less aversive than did older children or adults. By carefully manipulating instructions and comparisons of odors it was determined that the most important change with age was the tendency of the younger children to acquiesce. All the children found weaker concentrations of odors more pleasant than stronger concentrations of the same odor. The data suggest that hedonic properties of odors are learned.

\section{OTHER MAMMALS}

\section{Development of Preferences}

In 1899 , Small noted the reaction of infant rats to odors. At 3 to $4 \mathrm{hr}$ all odors were disagreeable, but by the fourth day they were able to 
discriminate between food odors, which they found "pleasurable," and various other substances such as violet and camphor. As responses indicating interest in the odors of cheese and milk often were made before they had tasted these substances, Small judged this to be an unlearned behavior. More recent observational investigations have shown that parts of the sniffing pattern begin to develop the day after birth (Bolles and Woods, 1964; Welker, 1964). Polypnea, the rapid expiration and inspiration associated with sniffing, develops first. By day 4 some synchronous movement of the tiny vibrissae is seen with full protraction and retraction by day 7 . Head movements for localization develop by day 8 . The full adult sniffing pattern is exhibited between day 11 and day 18 .

Rat pups were tested for olfactory preferences by placing them in a chamber, half of which had homecage wood shavings and half of which had clean shavings (Gregory and Pfaff, 1971). Nine- to twelve-day-old rats spent more time on the home shavings than on the clean shavings. Between 13 and 19 days of age, male and female rat pups preferred their own home shavings to those of a nonpregnant female, but not to those of another lactating female and litter. The ages correlated well with the development of sniffing as described by Welker (1964). Olfaction is apparently necessary for normal feeding of rat pups. Mortality of pups bulbectomized prior to 10 days of age was high (Rouger, Tobach, and Schneirla, 1967; Tobach, Rouger, and Schneirla, 1967; Singh and Tobach, 1975). Close observation of these pups revealed that they spent less time nursing and more time locomoting away from the mother than control animals (Singh and Tobach, 1972, 1975). Although the mothers were lactating and normal pups in the litter survived, bulbectomized pups had little or no milk in their stomachs. Rat pups peripherally anosmized ${ }^{2}$ with zinc sulfate took longer to attach to nipples than did their sham treated littermates and did not nurse sufficiently to maintain normal weight gain (Alberts, 1974b).

Nyakas and Endroczi (1970) found that 10-day-old rat pups located their mothers on the basis of olfactory cues. The pups went to their mother more frequently than to a nonlactating female or to a male. Investigation by the pups was stimulated by urine from the mother but the pups chose the mother rather than just her urine. The subsequent tests were repeated measures on the same animals, and the age of these choices was not given. Leon and Moltz $(1971,1972)$ determined that rat pups of-14-27 days of age chose their mother or another lactating female over a nulliparous female. Younger and older pups did not show these preferences. Rat pups decreased locomotor activity for 2-3 min after exposure to odors from their own mother (Schapiro and Salas, 1970) or when placed on fresh or homecage sawdust (Tobach et al., 1967). Bulbectomized 10- to 14-day-old rat pups did

${ }^{2}$ Anosmize from the Greek noun àvooun' (anōsme $\bar{e}$, without smell) $+i z e$ (to render) (C. Cheal, personal communication). 
not show the response to fresh or homecage sawdust (Rouger et al., 1967; Tobach et al., 1967). Maternal odor was an effective stimulus from day 2, but was most effective between 8 and 12 days. However, a decrease in locomotor activity at this early age may be general to any perceived stimuli as the only control used by Schapiro and Salas was no stimulus and similar responses can be elicited with sawdust odors (Tobach et al., 1967). Although the active response measured by Gregory and Pfaff (1971) could account for the lack of response until the ninth day in their study, it is likely that thermal factors are more important in maintaining the cohesion of the litter in younger animals (Leonard, 1974).

Rat pups demonstrated a preference for their mother starting at day 14 (Leon and Moltz, 1971, 1972). In an olfactory choice test where the stimulus animal was not visible, rat pups 14-27 days old chose the mother or another lactating female, but older and younger pups did not. The ages from 14 to 27 days correspond to the period in which pups move freely and retrieval by the mother decreases in frequency. Pups only chose females that were 14-27 days postpartum. The stimulation of suckling pups elicited an increase in the production of prolactin (Leon and Moltz, 1973) that induced increased feeding, thus yielding excess defecation (Leon, 1974). Included in elimination was caecotrophe from the caecum containing microbial organisms that produced the odor attractive to pups. Caecotrophe was also synthesized in the caecum of nonlactating females, but when feeding increased due to increased levels of prolactin excess caecotrophe was released with the feces. Caecotrophe attracted pups to the mother rat and also served as a weaning food (Leon, 1974). Ingestion of caecotrophe may introduce bacteria necessary for adult digestive function (Leon, 1974), and may strengthen the influence of mother's milk (Galef and Henderson, 1972) on the determination of the young rat's future food preferences. Rat pups responded to maternal odors at ages corresponding to those at which pups preferred home shavings. Perhaps the attraction of homecage shavings was in part due to caecotrophe from the mother remaining in the shavings (Leon, 1974). Pups were attracted to shavings of another lactating mother rat as much as to shavings of their own mother (Gregory and Pfaff, 1971).

In preference tests, hamster pups also spent more time on homecage bedding than on fresh bedding starting at 7-8 days of age (Devor and Schneider, 1974; Gregory, 1974). However, they differed from rats in that the preference began to decline at about 12 days (Devor and Schneider, 1974). Hamster pups preferred the odors of their homecage bedding over the odors from other hamsters, but, like rats, not over odors from another lactating mother and her pups. Gerbil pups at 12 days of age preferred homecage shavings to blank cotton or to nest shavings of a strange female, but no significant preference was shown between homecage shavings and shavings of another lactating female (Wallace, Thiessen, and Isaacks, 1975). Likewise, 
guinea pig pups tested at $1,2,3,8$, or 22 days spent equal time near their mother or another lactating female (Porter, Fullerton, and Berryman, 1973). Complete tests for specificity of attraction to maternal odors have not been conducted with hamsters, gerbils, or guinea pigs.

Infant rabbits, puppies, and kittens responded to presentation of jodoform, anise, or peppermint by a change in the rate of sucking (Bronshtein et al., 1960). The strongest response, to iodoform, habituated quickly in rabbits and puppies (and also in human infants), but not in kittens; 18 of 30 rabbits responded to the odor of cloves at 10 days of age but only 3 of 13 responded at 30 days. The authors believed that the change in response with age was due to a change in reactivity of the animals and not to a decrease in perception. Obviously, in this paradigm a negative response does not give any information on perception.

Infant wild rabbits, Oryctolagus cuniculus, may respond to a maternal pheromone (Mykytowycz and Ward, 1971). Breathing rate increased and rabbit nestlings stretched their heads toward a swab infiltrated with anal gland or inguinal gland secretions. The response was greater when the stimuli came from the mother than if from a strange male or female or a 2-to 3-mo-old juvenile. Urine from the mother also attracted the infant, but the anal gland secretion had the strongest effect.

Infant kittens show a position preference for a particular nipple when nursing (Rosenblatt, Turkewitz, and Schneirla, 1969; Rosenblatt, 1972). A series of experiments determined that kittens rely on tactile and olfactory cues to find the preferred nipple during the first 2 wk of development before vision is useful to them. When reared on an artificial mother with a textured rubber nipple, by the second day kittens spent more time nuzzling the nipple textured like the one associated with eating. Not until the third day could they discriminate the odor of a milk-filled nipple from a sealed nipple. If men's cologne or oil of wintergreen was associated with the nipple during feeding, the kittens would prefer a nipple of that scent for nuzzling. When kittens were reared by their mother, washing the nipple area prior to nursing disrupted the position of the kittens for a day or two and then they sucked at the preferred site again. If the area was shaved to remove the tactile cues nursing position was not disrupted. Bulbectomized kittens were unable to find the nipple or suckle from the mother although they learned to nurse from a bottle (Kovach and Kling, 1967).

Kittens a few days of age found their way from an adjacent corner of the cage to the home corner (Rosenblatt et al., 1969; Rosenblatt, 1972). When the home area was washed the kittens avoided it. From the first day kittens cried more intensely when they were placed in a strange cage. When returned to the homecage the crying diminished. It was concluded that olfactory cues are associated with the homecage and are used by the kittens to guide them to the home comer. 
Squirrel monkeys which have been reared with terrycloth-covered surrogates spent more time on one which they have used previously than they spent on clean ones (Kaplan and Russell, 1974). No color preference was seen when presented with a choice of a clean surrogate in the color of rearing or another color. An interpretation of Harlow's $(1962,1965)$ data, that suggested the importance of body contact, might include an increase in the concentration of olfactory cues which could accumulate on a cloth surrogate but not on a wire surrogate.

\section{Conditioning of Neonates}

Marr and Gardner (1965) rubbed rat pups each day from age 2 to 30 days with Yardley's Red Roses cologne, a mixture of $79 \% \mathrm{ETOH}$, glycerin, and methyl salicylate (oil of wintergreen), or with natural rat odors. In three-choice preference tests, at 30-45 days of age, a preference was shown for the odor of rearing by the rats reared with Yardley's perfume or normal odors, but not by animals reared with methyl salicylate. The authors suggested that methyl salicylate was toxic and that these animals were, at least, partially anosmic. In sexual tests with normally scented estrous females, more mounts were made by males that had been reared with natural rat odors than by males that had been reared with artificial odors. Mainardi, Marsan, and Pasquali (1965) found that control male mice also spent more time with females than did male mice reared with parents scented with the perfume, Voiletta di Parma. In a second study, from Marr's laboratory, infant rats were exposed to either acetophenone or ethyl benzoate (Marr and Lilliston, 1969). When exposed from 3 to 10 days of age or from 11 to 18 days of age, they demonstrated a preference for that odor when presented with both odors and a no odor control at 45 days. Pups exposed to one of the odors from 22 to 29 days did not show the preference at later testing.

Carter and Marr (1970) used a similar method to determine the responses of guinea pigs to ethyl benzoate and acetophenone after having been reared with one of the odors. Pups that had been exposed to the experimental odor for 22 days showed a preference for that odor at 15 and 22 days. When pups were exposed for only 15 days they showed the specific preference at 16 days, but after not smelling the odor for 7 days, only the ethyl benzoate subjects showed a preference. At 22 days the acetophenone group preferred normal rat odors over either experimental odor. When the stimulus was only present for 3 or 6 days during development, no specific preferences developed. Carter (1972) raised guinea pig pups for 21 days in cages in which air was circulated with ethyl benzoate, acetophenone, or no chemical. Pups from each group, further divided into three test groups, were tested at 25, 45, and 65 days of age in a 2-way choice apparatus to determine the preference for an odorant (ethyl benzoate, acetophenone, or normal animal odors) or clean air. 
Although the overall analysis of variance showed that the main effect of rearing with odor was significant, there was no preference specific to the rearing odorant. Animals reared with normal odors showed an aversion to ethyl benzoate and males preferred acetophenone. The animals were also tested for latency to approach lettuce in the presence of one of the three test odors. Males, but not females, showed some decrease in time to eat if they had been raised with an artificial odorant. None of the differences were very convincing. On the other hand, convincing data were presented on the mean sexual responsiveness of males. Males were tested for sexual behavior with estrous females at 75 days of age. A measure which included latency to touch the female, latency to mount, mounting, and a weighted measure of sex drive taken from Valenstein, Riss, and Young (1954) was used. More responsiveness was shown in the presence of the rearing odor than in the presence of the nonrearing odors. Females were not tested for sexual responsiveness.

Similar experiments with mice (Mus musculus domesticus) resulted in the opposite effects in male behavior (Mainardi et al., 1965). There was no difference between male mice that had been reared with perfumed parents and controls reared with normally scented parents in their preferential response to normal and perfumed estrous females. Normal females in this study preferred normal over perfumed males. The preference was lost if the females had been reared by perfumed parents. Neonatal dogs also showed a difference in behavior dependent on exposure to artificial odors (Fox and Himwich, 1965). If the mammae of the dam had been coated with anise oil, the experimental puppies displayed orientation and rooting reflexes when anise oil was presented at 5 days. Control animals did not respond to this stimulant.

Hamster pups that were reared on natural pine shavings spent equal or more time on peppermint and anise scented shavings, but avoided garlic or lemon scented pine shavings (Cornwell, 1975) or unfamiliar cedar shavings (Devor and Schneider, 1974; Cornwell, 1975). However, pups that were reared on beddings with added scent of garlic or lemon did not show aversion to the scent of rearing. Responses to scented bedding were recorded by 4 or 5 days of age. Preferences to homecage bedding were not seen until 7-8 days of age (Devor and Schneider, 1974; Gregory, 1974). Animals with bilateral olfactory bulbectomies or unilateral bulbectomy and contralateral lateral olfactory tract transection at day 3 showed no normal responses to cedar, pine, or homecage shavings (Cornwell, 1975). Animals with unilateral bulbectomy and unoperated controls showed normal responses.

Using a precocial species of rodent, the spiny mouse, Acomys cahirinus, a preference was conditioned at 1 day of age after exposure to ground cinnamon or ground cumin associated with the homecage for $24 \mathrm{hr}$ (Porter and Etscorn, 1974). Naive 1-day olds did not respond to these stimuli. A weaker, but significant, preference was shown with only $1 \mathrm{hr}$ of exposure, not associated with the homecage, at $2-12 \mathrm{hr}$ of age. Changes in alimentary 
responses were elicited by injecting lactating rats with citral daily for 10-30 days, imparting an odor, and perhaps a flavor, to the milk ingested by their pups (LeMagnen and Tallon, 1968). Compared to pups of noninjected mothers, female pups that consumed the altered milk for either 10 or 30 days ate more food with citral added at 40 days and at 60 days of age. Of the males, only the group receiving altered milk for 30 days and tested at 60 days of age preferred citral flavored food. All animals had lost the preference at 120 days. Weanling rats that had been reared with garlic fed dams or with garlic odors in the room demonstrated less aversion for garlic-laced mash than controls (Crockett, 1975). Adult tests were not reported.

Association of unusual odors with food increased the preference for food scented with the same odor in two species of Peromyscus (Drickamer, 1972). Young mice (21 days of age) and adult mice were provided with food scented with pine, wintergreen, or anise for $2 \mathrm{wk}$. The other two scents were present but not paired with food. Preference tests showed that, although the behavior of both species was modified, $P$. leucopus demonstrated more plasticity in food selection than did $P . m$. bairdi. The young and the adult $P$. leucopus consumed more of the diet scented with the conditioned odor when offered all three combinations of food and odor in an immediate test. The young $P$. $m$. bairdi preferred the scent of training in an immediate test and in a test 30 days later, but there was no modification of the adult consumption. To test the appetitive effects of conditioning, scented food was presented behind sticks which the mice had to chew through to obtain the food of the preferred scent. This test also demonstrated the modification of behavior of both young and adult $P$. leucopus, but only the young $P . m$. bairdi responded to the scent of conditioning. Peromyscus leucopus normally has a wide-range of ecological habitation, living in forest brushlands, fields, and bogs. Peromyscus m. bairdi's ecological distribution is restricted to fields and meadows. The authors suggested that the differences in modifiability of feeding behavior were due to inherited differences in the capacity to respond to ontogenetic experience.

\section{Influence of Early Experience on Adult Behavior}

Early olfactory experience influences the sexual maturation of female mice. Continual exposure of immature females to intact male mice, to soiled bedding from intact males (Vandenbergh, 1967, 1969; Fullerton and Cowley, 1971), or to urine from intact males (Cowley and Wise, 1972; Colby and Vandenbergh, 1974) accelerated first vaginal estrus. Whether sexual maturation is associated with a general acceleration of physical development is an open question. Cowley (Fullerton and Cowley, 1971; Cowley and Wise, 1972) found that females that were housed with males gained weight at a more rapid rate than controls. On the other hand, Vandenbergh (Vandenbergh, 1967, 
1974; Vandenbergh, Drickamer, and Colby, 1972) discerned no differences in weight between experimental and control animals. When females were exposed to males at a younger age, they attained sexual maturity at a younger age than those exposed later (Vandenbergh, 1967). However, older animals exhibited vaginal estrus in fewer days following stimulation than did younger animals (Colby and Vandenbergh, 1974). Exposure to a male for $4 \mathrm{hr}$ daily from 4 to 18 days of age also resulted in earlier vaginal estrus (Kennedy and Brown, 1970). Exposure to urine from preputialectomized male mice or intact male rats also facilitated female maturation (Colby and Vandenbergh, 1974). If the females were isolated from other females they matured earlier than if they were housed with other females, were exposed to bedding of grouped females (Fullerton and Cowley, 1971; Drickamer, 1974), or to urine from grouped females (Cowley and Wise, 1972; Colby and Vandenbergh, 1974). Increasing the stimulus group of females from one to nine increasingly delayed sexual maturation. The inhibitory effects of a female pheromone and the stimulating effects of a male pheromone influenced maturation simultaneously in opposite directions. Thus, in an isolated female exposed to male stimuli, puberty was hastened to 30 days. In grouped females without male stimulation, puberty was posponed as late as 60 days (Vandenbergh, 1974).

Using pregnant mare serum or human chorionic gonadotropin, ovulation in immature mice was induced in the presence of an adult male mouse (Zarrow, Estes, Denenberg, and Clark, 1970). Ovulation did not occur if an immature or castrated male was used, or if the female was bulbectomized. The amount of facilitation of ovulation varied with the strain of mice used (Zarrow, Christenson, and Eleftheriou, 1971). Early sexual maturity after exposure to odors of male mice may be another indication of the Whitten effect of estrus synchrony. It was suggested that male odors stimulate a release of luteinizing hormone and follicle stimulating hormone from the pituitary, initiating ovulation (Bronson, 1971). However, the measurement of circulating hormones in juvenile females indicated only luteinizing hormone is released by initial exposure to male stimuli (Bronson and Desjardins, 1974). Young female mice were exposed to stimuli from males for $36-48 \mathrm{hr}$. In the first 1-3 hr there was a four- to five-fold increase in plasma luteinizing hormone, followed by a 15 - to 20 -fold increase in estradiol with no change in circulating follicle stimulating hormone and progesterone. A second peak of estradiol occurred on the second day. Changes in serum luteinizing hormone, follicle stimulating hormone, and plasma progesterone on the afternoon of the third day mimicked the normal ovulation sequence. Male stimulation for $12 \mathrm{hr}$ was not sufficient to complete the course of hormonal secretion even though the immediate sequential changes in luteinizing hormone and estradiol were induced. Injections of estrogen for 2 days completely mimicked the exposure to males in initiating the hormonal sequence leading to ovulation (Bronson, 1975). These data indicate that the presence of male mice elicits the first day 
estrogen secretion by the release of luteinizing hormone, thereby initiating the ovulatory sequence.

In an investigation of the effect of early olfactory input on agonistic behavior, Stark and Hazlett (1972) concluded that Peromyscus maniculatus bairdi and Mus musculus that were reared with odors and sounds from both species won more interspecific encounters than if they were reared in a room containing only conspecific animals. Rat-reared mice were less aggressive, displayed less activity in an open field, and secreted less plasma corticosterone after exposure to a novel stimulus than did mice that were normally reared (Hudgens, Denenberg, and Zarrow, 1968; Denenberg, Rosenberg, Paschke, Hess, Zarrow, and Levine, 1968). However, it appears that distance sensory cues, including olfaction, do not mediate the physiological difference between rat- and mouse-reared animals as mice reared with a mesh wall separation from the rat gave no different plasma corticosterone response than controls exposed to mouse stimuli (Denenberg, Paschke, Zarrow, and Rosenberg, 1969).

Cross-fostering of inbred laboratory mice (Mus musculus, C57RB/cdJ) and wild-caught pygmy mice (Baiomys taylori ater) also resulted in changes in social behavior (Quadagno and Banks, 1970). Open field behavior of both species changed in the direction of the rearing species and encounters between individuals showed more positive-type responses between cross-fostered animals than between conspecifics if they had not been reared together. At 75-85 days of age, cross-reared females of both species and cross-reared male Mus spent significantly less time near conspecifics when given a choice of the two species than did controls. The greater influence of early stimulation on females was again demonstrated as cross-fostered females of both species had a larger change in preference than did males. It was suggested that differential handling by the dams could account for the change in activity level of cross-fostered pups. The effects of olfactory cues are unknown as no attempt was made to fractionate the various sensory inputs.

In black-tailed deer early olfactory cues may be very important to later behavior (Müller-Schwarze and Müller-Schwarze, 1971). When a male blacktailed deer was reared with a surrogate mother scented with the ischiadic, or rump, gland secretion of a male pronghorn, it spent more time near a surrogate baited with pronghorn scent than near surrogates baited with the tarsal gland scent of female black-tailed or mule deer at 15 and 33 days of age. At 2.5 mo the deer was penned with three females, one of each species. The fawn spent significantly more time with the pronghorn than with either the black-tailed or the mule deer.

Observational and experimental data implied that playful interactions were stimulated by a pheromone present in spring-born, but not autumn-born shorttailed voles, Microtus agrestis (S. Wilson, 1973). The author speculated that the seasonal difference in the behavior of the juveniles is reflected in the sexual behavior of the adult males. In turn, the sexual behavior of the adults of the species determines the annual population cycle. 


\section{Behavioral Effects of Early Olfactory Bulbectomy}

This paper has cited a number of experiments concerning the immediate effects of olfactory bulbectomies. Neonatal bulbectomies resulted in high mortality (Rouger et al., 1967; Tobach et al., 1967; Singh and Tobach, 1975) accompanied by subnormal gain in weight (Schönfelder and Schwartze, 1971; Singh and Tobach, 1975) and an increase of locomotor activity away from the mother (Singh and Tobach, 1972, 1975). The effects resulted from a loss of orientation to and suckling from the mother (Kovach and Kling, 1967; Singh and Tobach, 1972, 1975). As similar effects were found with peripherally anosmized animals (Alberts, 1974b), it would appear that olfaction mediated these behaviors. Hamsters with neonatal bulbectomies gave no normal responses to cedar, pine, or homecage shavings (Cornwell, 1975). In female rats, early bulbectomy (Sato, Haller, Powell, and Henkin, 1974; Pollak and Sachs, 1975), olfactory stalk transection (Kling, 1964), or peripheral anosmia (Orbach and Kling, 1966) delayed vaginal opening. Females bulbectomized at 20 days of age did not differ from controls in age of vaginal opening (Sato et al., 1974). Delayed vaginal opening was accompanied by absence of corpora lutea in the ovaries around 42 days of age and decreased concentrations of pituitary luteinizing hormone and smaller uterine weights. Vaginal opening was also delayed by prevention of genital licking, but not by blinding (Orbach and Kling, 1966). Premature sexual maturation could not be induced by male mice in bulbectomized young female mice (Zarrow et al., 1970). This evidence combined with evidence showing that sexual maturity can be facilitated by airborne stimuli or by urine from intact males, suggests that olfaction mediates the effect of facilitation of sexual maturity.

The conclusions may be different in behaviors tested in adulthood after early bulbectomy. Although $50 \%$ of adult male mice killed and ate mice pups, males 22 days old normally did not. However, males bulbectomized at day 18 , and tested at day 22 cannibalized the young (Gandelman, 1973). No test was made with peripherally anosmized animals. Female rats bulbectomized at 6 days of age showed normal maternal behavior with no evidence of cannibalism (Pollack and Sachs, 1975). Only when bulbectomy experiments are combined with other research can one determine if the removal of the olfactory sense is responsible for changes in behavior. Winans and Powers (1974) demonstrated that bulbectomy of 12-day-old male hamsters resulted in loss of adult sexual behavior. The finding demonstrated that early olfactory bulbectomy does not decrease deficits obtained in hamsters bulbectomized in adulthood (Murphy and Schneider, 1970). It appears, however, that the loss of the sense of smell per se is not responsible for the impaired sexual behavior as male hamsters that were peripherally anosmized continued to mate (Powers and Winans, 1973). The most recent evidence suggests that the vomeronasal organ may be the influential structure (Powers and Winans, 1975). Adult female hamsters, which had been bulbectomized at 10 days of age, demonstrated less scent 
marking, less aggression during pregnancy, no social interaction with males during lactation, and sometimes destroyed their litters (Leonard, 1972). However, most of these changes in behavior were exhibited by unilaterally lesioned animals as well as the bilaterally bulbectomized. Anosmia was not induced peripherally to separate the effects of the sense of smell from central processes.

In the rat, there are conflicting data on the effects of early bulbectomy on adult male sexual behavior. Only minor deficits were shown in experienced male rats bulbectomized postpuberally (Heimer and Larsson, 1967), but drastic impairment of mounting, intromission, and ejaculation occurred after bulbectomy at day 30 (Wilhelmsson and Larsson, 1973). If anosmized animals were isolated from day 10 all sexual behavior was abolished. On the other hand, male rats, bulbectomized at 6 days of age, showed first intromission and ejaculation at ages similar to controls (Pollak and Sachs, 1975). The different results could be due to the age of surgery. Another difference was that the male pups in the social group of Wilhelmsson and Larsson's study were reared with two female pups while no female pups were used in Pollak and Sachs' study. A third possibility is the extent of surgical damage. Olfactory bulbectomy often includes removal of the accessory olfactory bulb which is a completely separate structure histologically from the main olfactory bulb. It receives input from the vomeronasal organ and projects to a specific area of the amygdala. There is no overlap of the projections from the main olfactory bulb and the accessory olfactory bulb in the brain areas (Winans and Scalia, 1970; Scalia and Winans, 1975). As the accessory olfactory bulb is not mentioned by Wilhelmsson and Larsson or Pollak and Sachs, it cannot be determined if the surgical procedures resulted in equivalent damage to this structure. Males that received bilateral transection of the olfactory stalk at 6 days of age did not mate as adults (Kling, 1964). Males, peripherally anosmized by a drop of $10 \%$ formalin into the nostrils, coagulation of the olfactory mucosa with direct current, or aspiration of the olfactory mucosa, had normal onset of puberty as measured by testicular descent, first spontaneous seminal discharge, and appearance of the first sperm. However, only $20 \%$ of these males mated normally as adults (Orbach and Kling, 1966). Eighty percent of blinded males also failed to mate as adults and, although they had normal testes as adults, they had smaller testes during development than normal males. Even if it were known whether the mucosa had regenerated in the anosmized animals, it would be difficult to understand the conflicting effects of olfactory deprivation experiments on the sexual behavior of the male rat.

\section{FISH AND AMPHIBIANS}

\section{Fright Reaction}

Fright reactions may be elicited from many species of fish and amphibians by a substance from the skin of other animals of the same species 
(Pfeiffer, 1963; Bardach and Todd, 1970). By using an extract from the skin, it was determined that fish perceive the stimulus by use of their chemical senses. There are two lines of evidence that the reaction is mediated by olfaction. Cutting the olfactory nerves eliminated the response, and the degree of sensitivity was greater than that usually demonstrated by the taste system. The fright reaction could not be elicited in recently hatched fry but developed early in life (Pfeiffer, 1963, 1974). The substance could be found in the skin a few days before the response appeared. The stage of development, rather than absolute age, determined the onset of the response. For instance, in the zebra fish, Brachydanio rerio, alarm substance was present at 20 days and the response occurred at 28 days. The respective ages were 28 and 42 days for the redskin shiner, Richardsonius balteatus, and 38 and 51 days for the minnow, Phoxinus laevis. Tadpoles, on the other hand, responded to alarm substance immediately upon hatching.

\section{Migration}

Many species of fish are hatched in a stream, later migrate to open waters, and then return to the original stream to spawn. A variety of mechanisms undoubtedly interact in the performance of this feat, but one of the most popular hypotheses offered to explain the final stage of migration, the choice of a particular stream, is that the odors present during development are conditioned or "imprinted." There is much evidence that the fish are following the odors present during presmolting back to the site from which the fish originally migrated. Research from Hasler's laboratory (Walker and Hasler, 1949; Hasler and Wisby, 1950, 1951; Madison, Scholz, Cooper, Horrall, Hasler, and Dixon, 1973) suggested that minerals and vegetative odors of the homestream were critical. Alternatively, chemicals released from other members of the same species may be the conditioning odor (Nordeng, 1971; Solomon, 1973; D $\phi$ ving, Nordeng, and Oakley, 1974).

Home stream hypothesis. Laboratory training experiments determined that bluntnose minnows, Hyborhynchus notatus, could discriminate between two different species of aquatic plants based on chemical stimuli alone (Walker and Hasler, 1949). Minnows were able to detect a rinse from a sprig of aquatic plant which had been diluted 1:10,000 and then streamed into a 7-gallon aquarium. Discrimination was also demonstrated to water from two different Wisconsin streams when they were differentially reinforced (Hasler and Wisby, 1951). Chemical analysis and fractionation indicated that the odorous components were volatile and aromatic organic substances (Hasler and Wisby, 1951; Idler, McBride, Jonas, and Tomlinson, 1961). Fish could detect phenols at concentrations far below man's threshold (Hasler and Wisby, 1950). The discriminations were eliminated by heat cauterization of the olfactory epithelium.

It should be noted that the foregoing experiments demonstrated discrimination and not preference. In preference tests by Sutterlin and Gray 
(1973), hatchery-reared Atlantic salmon, Salmo salar, but not wild salmon, chose river water with an effluent from the hatchery over plain river water. They lost this preference if $\mathrm{CuSO}_{4}$ was added to the hatchery effluent. The hatchery effluent would, of course, contain both mineral-vegetative stimuli and fish-produced chemicals. Alewives, Alosa pseudoharengus, a species of migrating herring, also preferred home water when a choice between two lake or pond waters was presented (Thunberg, 1971). Plugging the nares disrupted the response.

Electrical activity of the olfactory bulb (EEG) has been used to support the homestream hypothesis. Although the early recordings made of olfactory bulb EEG suggested that Pacific salmon respond specifically to their own homestream water (Hara, Ueda, and Gorbman, 1965; Ueda, Hara, and Gorbman, 1967), more recent research does not support this hypothesis (Oshima, Hahn, and Gorbman, 1969; Cooper and Hasler, 1973, 1974). Cooper and Hasler criticize the EEG technique stating that the electrical potentials do not always correlate with behavioral responses. However, they are talking of preferences correlating with electrical responses. One would expect discrimination, but not preference, to correlate with the magnitude of an electrical response when testing various chemicals.

Much of the early tagging field research produced very low return capture of fish. Two to three percent (Clemens, Foerster, and Pritchard, 1939) was considered good evidence of return to the homestream (Hasler and Wisby, 1951). The conviction that salmon return to their homestream is based on the low catch of tagged fish in other streams and to the many different experiments with very similar results.

Donaldson and Allen (1957) determined that conditioning and not genetic inheritance was responsible for homing. When Coho salmon eggs were moved to a different stream, fish returned to the stream of release and not to the ancestral stream. The sensitive period for olfactory conditioning in Coho salmon, Oncorhyncus kisutch, may be related to smolting (Madison et al., 1973). Coho salmon returned to a facility where they had been held for $36-48 \mathrm{hr}$ when they were smolting and not to the release location one-half mile away. On the other hand, Atlantic salmon were reared to young smolts in one stream, then held until smolting (a period of a month) in another stream, tagged at a third location (a period of a week), and then released at the third site or at a fourth site (Carlin, 1968, as discussed in Madison et al, 1973). The fish returned to the stream of release indicating that the stream of release, and not the developmental age or postsmolting age, is the determinant of where conditioning occurs in Atlantic salmon. The sensitive age may be related to the age at which migration occurs normally and the distance the fish must travel for migration to open water (Madison et al., 1973).

Recent investigations of the homestream variation of the olfactory hypothesis have used an artificial, rather than a natural, odor for conditioning 
of Coho salmon and three independent methods of analysis: census, ultrasonic tracking, and EEG recording (Madison et al., 1973). Fifteen-month-old juvenile salmon were exposed for $5-6 \mathrm{wk}$ to morpholine added to a neutral water supply which contained no natural stream chemicals. After smolting the fish were released directly into Lake Michigan. Morpholine was later added to a neutral stream near the location where the smolts were released. In the spring of $1971,16,000$ salmon were released, half of which had been conditioned to morpholine; 216 of the 8000 conditioned and 28 of 8000 unconditioned salmon were recaptured in the stream scented with morpholine. This is a significantly different ratio from what would be predicted by chance, but only a $2.7 \%$ return. Madison et al. (1973) concluded that salmon will return to a morpholine scented stream after conditioning pre- and postsmolting. The tracking experiments demonstrated that juvenile conditioning with morpholine had a strong influence on adult behavior (Madison, et al., 1973). Adult salmon with an ultrasonic transmitter inserted in the esophagus were tracked in Lake Michigan. Ten adult salmon which had been conditioned to morpholine at smolting ceased migrating when they reached a decoy area in which morpholine was present. They milled around the area for up to several hours before moving away. Five unconditioned fish continued directly through the morpholine decoy area and five conditioned fish passed through the area when no morpholine was present. EEG responses to morpholine were specific in trained fish, supporting the census and tracking data in establishing that a substance experienced early in life may have an effect on behaviors and physiology in adulthood (Dizon, Horrall, and Hasler, 1973; Cooper and Hasler, 1973, 1974).

Pheromone hypothesis. The EEG data of Oshima, Hahn, and Gorbman (1969) seems to support a pheromone hypothesis. The best responses were elicited by water which had been used to store fish. The authors noted that if conspecifics were stored in the water a bigger response was elicited than if different species had lived in the water. Cooper and Hasler (1973) commented on the influence (or contamination) of chemicals from fish on the EEG, stating that the fish may leave "incidental stimulatory products": organic materials similar to an effluent from a factory discharge. In another paper from the same laboratory, Madison et al. (1973) suggest the possibility that conspecific odors of fingerling salmon in the homestream may be a major source of the conditioning odorant.

Upon release, char, Salmo alpinus, in northem Norway returned to their parental river after being reared for $3 \mathrm{yr}$ in southern Norway, suggesting that pheromones of the same population attracted the migrating fish (Nordeng, 1971). That char are capable of responding differentially to chemicals from different char populations has been demonstrated with recordings from single units of the olfactory bulb (D $\phi$ ving, Nordeng, and Oakley, 1974). Solomon (1973) suggested the return of Atlantic salmon, Salmo salar. in England is 
influenced by a stock specific pheromone from fish in the stream. The annual catch of fish at a small fishery where fish had not spawned increased dramatically when salmon ova were placed in the river. The increase in catch was too soon to have been the same fish which migrated from that river. Sutterlin and Gray (1973), on the other hand, doubted that a pheromone was responsible for homing. Twenty-three hundred wild Atlantic salmon were caught in their experiment. Ninety-eight percent were found in the river and $2 \%$ were in the trap at the hatchery where many young fish were reared. If pheromones attracted the fish, wild fish would be expected to be lured to this rich source of pheromones. Although wild fish did not return to the hatchery, $67 \%$ of the catch of marked salmon which had been released from the hatchery were found in the hatchery trap.

In summary, the three-way correspondence of data from the census, tracking, and EEG data strongly supports the conclusion that fish can be conditioned to morpholine. However, the fact that fish can be conditioned to an unnatural stimulus doesn't argue that normal fish are necessarily conditioned to a mineral or vegetative stimulus. It would seem more likely that fry are conditioned to all the diverse odors surrounding them. Surely the odors from the other fish present must be an important component of the conditioning odorant. An experiment designed to partition the effects of various components of the homestream odor might show that vegetative, mineral, and animal odors have an additive function in luring fish to a particular stream.

\section{DISCUSSION}

The wide variety of organisms in which the influence of olfaction in development has been demonstrated illustrates an important role for chemosenses in the behavior of animals from various phyla. In many organisms (such as kittens), olfaction can guide behavior before vision and audition are sufficiently developed to be useful (Rosenblatt et al., 1969; Rosenblatt, 1972). In some species normal development and growth will not occur in anosmized animals (Kovach and Kling, 1967; Singh and Tobach, 1972, 1975; Alberts 1974b). Although olfactory bulbectomy experiments need to be interpreted with caution (Alberts, 1974a), research which has included methods to peripherally anosmize animals, or several lines of evidence pointing in the same direction, lead to conclusions as to olfactory involvement in behavior. The immediate effects of anosmia on neonates indicate that the sense of olfaction is necessary for feeding and returning to the nest (Rouger et al., 1967; Tobach et al., 1967; Kovach and Kling, 1967; Singh and Tobach, 1972, 1975; Alberts, 1974b). The evidence for the influence of olfactory stimuli to induce early sexual maturation comes from bulbectomy experiments 
(Sato et al., 1974; Pollak and Sachs, 1975), olfactory stalk transection (Kling, 1964), peripheral anosmia (Orbach and Kling, 1966), and from experiments using urine as the stimulus (Cowley and Wise, 1972; Colby and Vandenbergh, 1974). The conclusions concerning adult behavior following infant bulbectomy are more difficult to define. Although early bulbectomy will eliminate male sexual behavior in the hamster (Winans and Powers, 1974) the effects of peripheral anosmia during development are not known. Deprivation of olfactory input in female infant rats clearly delays sexual development, but the significance of the olfactory bulbs and the sense of smell for the development of sexual behavior in the male rat awaits further clarification. In Leonard's (1972) experiment, it was not determined whether the disruption of social behavior was due to the loss of olfactory input or to other more central disruptions. Other ontogeny research showed that olfactory cues can be learned, with or without other sensory cues, to modify later behavior (as in conditioning of rodents and fish).

The ontogeny of species-specific preferences is not fully understood. A genetic program can be termed as open (modifiable or plastic) or closed (Mayr, 1974). The conditioning experiments described in this paper indicate that the genetic program is sufficiently open to allow interaction with the environment during development to ensure the most adaptive mating. Although courting signals have been considered to be closed genetic programs, species with longer life spans and more extensive central nervous systems may be expected to have more open genetic systems (Mayr, 1974). From the data that mammals will change their preferences if reared with an artificial odor (Marr and Gardner, 1965; Mainardi et al., 1965; Marr and Lilliston, 1969; Carter and Marr, 1970; Carter, 1972; Madison et al., 1973; Cornwell, 1975) or another species (Müller-Schwarze and Müller-Schwarze, 1971; Stark and Hazlett, 1972), we can infer that in a natural situation the odors from the parent strengthen the normal ontogenetic development. The difficulty in establishing a long-term change in preferences may, in part, indicate the lack of openness of the genetic program. On the other hand, it may also result due to the inability to remove natural odors from the rearing condition.

One might suggest that the plasticity of the developing organism allows more influence of environmental stimuli than in adults, but there is little data available. Peromyscus $m$. bairdi changed feeding habits based on the association of odors with food when young, but not as adults (Drickamer, 1972). The difference in adult modifiability in $P . m$. bairdi and $P$. leucopus may be due to species differences based on differing ecological pressures, or it may be the result of the particular paradigm. Using the conditioned aversion paradigm, it was possible to change a rat's drinking preference based on olfactory cues (Supak, Machrides, and Chorover, 1971). Animals were allowed to drink a preferred concentration of sodium chloride $(\mathrm{NaCl})$ in association with odors for several days. They were then conditioned by presenting lithium chloride 
( $\mathrm{LiCl}$ ) with one of the odors. As rats do not discriminate $\mathrm{LiCl}$ from $\mathrm{NaCl}$ they drank enough to become ill. In a posttest the rats no longer drank $\mathrm{NaCl}$ when paired with the conditioning odor, but continued to ingest $\mathrm{NaCl}$ paired with other odors. It would be interesting to know if adult $P$. m. bairdi would give the same response. Mayr (1974) suggests that noncommunicative behavior, such as feeding, needs to be flexible, so the genetic program can be expected to be more open than in communication systems such as sexual attractants.

Early conditioning to an odor may modify more than one behavior (Carter, 1972). Perhaps neonates develop nonspecific preferences which can be demonstrated in various social situations, whereas adults only show preferences specific to the reinforcement paradigm. Confirmation of such speculation awaits further testing. The strength of a conditioned preference is dependent on the experimental conditions as well as the species used. When the odor was rubbed on rodents (Marr and Gardner, 1965; Marr and Lilliston, 1969; Carter and Marr, 1970), mixed with bedding (Cornwell, 1975; Porter and Etscorn, 1974), or paired with food (Drickamer, 1972) more specific preferences developed than when the odorant was present diffusely in the air (Carter, 1972; Porter and Etscorn, 1974). If contiguity is important, the odor would be more effective when associated closely with a reinforcer such as food, home bedding, or conspecifics. However, the difference seen in conditioning effectiveness may also be due to the testing situations. When the stimulus is associated with another animal (as in the three-choice tests used by Marr and Gardner, Marr and Lilliston, and Carter and Marr) it may mean something different to the animal than when it's conveyed in an airstream depending on the animal's location in a cage on a tilt table (Carter, 1972). If the artificial odor reacted with normal odors during development the actual stimulus may be a compound of this interaction. Fish probably respond to a similar compound stimulus in finding their way to the homestream.

Another speculation is that releasing, or signaling, pheromones may be modifiable by early experience but primer pheromones are not. In mammalian usage, signaling pheromones result in a more or less immediate change in motor activity of the recipient animal and priming pheromones initiate neuroendocrine and endocrine activities (Bronson, 1974). The experiments on modified preferences (Hudgens et al., 1968; Denenberg et al., 1968, 1969; Quadagno and Banks, 1970; Müller-Schwarze and Müller-Schwarze, 1971) suggest that pheromones which signal sexual attraction are influenced by exposure to these odors at an early age. Experiments on the modifiability of response to primer pheromones have not been done. It would be interesting to know if immature ovulation of female mice could be facilitated by a different species if the female had been raised with that species. Would cross-fostering change the species to which pregnancy block could be demonstrated in mice?

Several experimenters have found a greater responsiveness in females after early olfactory experience than in males (Mainardi et al., 1965; LeMagnen and Tallon, 1968; Quadagno and Banks, 1970). The greater 
responsiveness of females to social stimuli might be advantageous as females invest a greater proportion of their total reproductive capacity in each conception. On the other hand, the male can inseminate many females so that leaving a few sperm in inappropriate partners does not greatly lower his potential progeny. The sex differences seen in mice suggested that females have the selective role in mating (Quadagno and Banks, 1970; Doty, 1974). On the basis of field observation, Selander and Giller (1961) hypothesize that female grackels, Cassidix mexicanus and $C$. major, prevent hybridization by distinguishing between males on the basis of behavioral differences in displays and vocalizations. Males show no preferences for females of their own species. In the laboratory, the female blue gourami, Trichogaster trichopterus, requires a period of days to adapt to the environment before mating will occur, whereas the male will mate the day he is introduced to a tank suggesting the greater role of the female in mate selection (Cheal, 1973b; Cheal and Davis, 1974).

The male-female difference in responsiveness to olfactory experience also reflects the male-female differences in consummatory behavior in other paradigms. Female rats show a greater saccharin preference than males (Valenstein, Kakolewski, and Cox, 1967) and female rats eat more and gain more weight than males after hypothalamic lesions (Valenstein, Cox, and Kakolewski, 1969). No differences were found in the ability of male and female mice in the discrimination of individual mice based on olfactory cues (Kalkowski, 1967). It seems likely, therefore, that male-female differences in mammalian consummatory behavior are not due to a difference in the perception of odors, but rather to motivational, and perhaps hormonal, differences.

The human data demonstrate that newborn infants also perceive odors, and sensitivity to the odors increases over the first few days of life (Bronshtein et al., 1960; Engen et al., 1963; Lipsett et al., 1963). Although conditioning experiments on babies have not been, and probably will not be, performed, for ethical reasons, the suggestion has been made that humans may form associations based on early olfactory experiences in a manner similar to animals (Cheal, 1973a; Vandenbergh, 1974). Engen's (1974) data suggest that social and alimentary preferences of humans are modified by the early olfactory environment. Social stimuli, mediated by olfaction, may also influence the establishment of sexual identity (Kalogerakis, 1963), modify the time course of sexual development, and partially account for the acceleration of menarche noted in the past $100 \mathrm{yr}$ (Vandenbergh, 1974). Although complete experimental data in humans may not be possible, survey and preference data could elucidate these possibilities.

\section{REFERENCES}

Alberts, J. R. (1974). Producing and interpreting experimental olfactory deficits. Physiol. Behav. 12, 657-670. (a) 
Alberts, J. R. (1974). "The Role of Olfaction and Olfactory Experience in Maternal and Sibling Interactions of the Rat." Paper presented at APA. (b)

Bardach, J. E. and Todd, J. H. (1970). Chemical communication in fish. In J. W. Johnston, Jr., D. G. Moulton, and A. Turk (Eds.), "Advances in Chemoreception, Vol. 1, Communication by Chemical Signals," pp. 205-240. New York: AppletonCentury-Crofts.

Birch, M. C. (1974). "Frontiers of Biology, Vol. 32, Pheromones." New York: American Elsevier Publishing.

Bolles, R. C. and Woods, P. J. (1964). The ontogeny of behaviour in the albino rat. Anim. Behav. 12, 427-441.

Bronshtein, A. I., Antonova, T. G., Kamenetskaya, A. G., Luppova, N. N., and Sytova, V. A. (1960). On the development of the functions of analyzers in infants and some animals at the early stage of ontogenesis. In "Problems of Evolution of Physiological Functions" [Transl. from Russian] pp. 106-116. Washington, D.C.: The Department of Health, Education, and Welfare.

Bronson, F. H. (1971). Rodent pheromones. Biol. Reprod. Suppl. 3, 344-357.

Bronson, F. H. (1974). Pheromonal influences on reproductive activities in rodents. In M. C. Birch (Ed.), "Frontiers of Biology, Vol. 32, Pheromones," pp. 344-365. New York: Elsevier Publishing.

Bronson, F. H. (1975). Male-induced precocial puberty in female mice: Confirmation of the role of estrogen. Endocrinology 96, 511-514.

Bronson, F. H. and Desjardins, C. (1974). Circulating concentrations of FSH, LH, estradiol, and progesterone associated with acute, male-induced puberty in female mice. Endocrinology 94, 1658-1668.

Bronson, F. H. and Dezell, H. E. (1968). Studies on the estrus-inducing (pheromonal, action of male deermouse urine. Gen. Comp. Endocrinol. 10, 339-343.

Bruce, H. M. (1970). Pheromones. Brit. Med. Bull. 26, 10-13.

Carlin, B. (1968). (as cited in Madison et al., 1973). "Migrations of Salmon." The third in a three part lecture series on the Atlantic salmon. The Atlantic Salmon Association, Montreal, Quebec, Canada.

Carter, C. S. (1972). Effects of olfactory experience on the behaviour of the guinea pig (Cavia porcellus). Anim. Behav. 20, 54-60.

Carter, C. S. and Marr, J. N. (1970). Olfactory imprinting and age variables in the guinea pig, Cavia porcellus. Anim. Behav. 18, 238-244.

Cheal, M. L. (1973). Evolutionary aspects of olfactory stimuli. et al. 3, 64-71. (a)

Cheal, M. L. (1973). "Reproductive Behavior: Regulation in Trichogaster trichopterus, an Anabantid Fish." Ph.D. Thesis. Univ. Michigan. Ann Arbor, Michigan: University Microfilms 74-3597. (b)

Cheal, M. L. and Davis, R. E. (1974). Sexual behavior: Social and ecological influences in the Anabantoid fish, Trichogaster trichopterus. Behav. Biol. 10, 435-445.

Cheal, M. L. and Sprott, R. L. (1971). Social olfaction: A review of the role of olfaction in a variety of animal behaviors. Psychol. Rep. 29, 195-243.

Clemens, W. A., Foerster, R. E., and Pritchard, A. L. (1939). The migration of Pacific salmon in British Columbia waters. Amer. Ass. Advan. Sci. 8, 51-59.

Colby, D. R. and Vandenbergh, J. G. (1974). Regulatory effects of urinary pheromones on puberty in the mouse. Biol. Reprod. 11, 268-279.

Cooper, J. C. and Hasler, A. D. (1973). An electrophysiological approach to salmon homing. Fish. Res. Bd. Canada Tech. Rep. 415, 1-44.

Cooper, J. C. and Hasler, A. D. (1974). Electroencephalographic evidence for retention of olfactory cues in homing Coho salmon. Science 183, 336-338.

Cornwell, C. A. (1975). Adaptation to complex rearing odors by golden hamster pups. Behav. Biol. 00, 00-00. 
Cowley, J. J. and Wise, D. R. (1972). Some effects of mouse urine on neonatal growth and reproduction. Anim. Behav. 20, 499-506.

Crockett, D. P. (1975). "Rats' Food Preferences are Determined by Maternal Diet." Paper presented at Eastern Psychological Association, New York.

Denenberg, V. H., Rosenberg, K. M., Paschke, R., Hess, J. L., Zarrow, M. X., and Levine, S. (1968). Plasma corticosterone levels as a function of cross-species fostering and species differences. Endocrinology 83, 900-902.

Denenberg, V. H., Paschke, R., Zarrow, M. X., and Rosenberg, K. M. (1969). Mice reared with rats: Elimination of odors, vision, and audition as significant stimulus sources. Develop. Psychobiol. 2, 26-28.

Devor, M. and Schneider, G. E. (1974). Attraction to home-cage odor in hamster pups: Specificity and changes with age. Behav. Biol. 10, 211-221.

Dizon, A. E., Horrall, R. M., and Hasler, A. D. (1973). Long-term olfactory "memory" in coho salmon, Oncorhynchus kisutch. Fish. Bull. Nat. Oceanic Atmos. Adm. 71, 315-317.

Donaldson, R. and Allen, G. H. (1957). Return of silver salmon Oncorhynchus kisutch (Walbaum) to point of release. Trans. Amer. Fish. Soc. 87, 13-22.

Doty, R. L. (1974). A cry for the liberation of the female rodent: Courtship and copulation in Rodentia. Psychol. Bull. 81, 159-172.

D $\phi$ ving, K. B., Nordeng, H., and Oakley, B. (1974). Single unit discrimination of fish odours released by char (Salmo alpinus L.) populations. Comp. Biochem. Physiol. 47A, 1051-1063.

Drickamer, L. C. (1972). Experience and selection behavior in the food habits of Peromyscus: Use of olfaction. Behaviour 41, 269-287.

Drickamer, L. C. (1974). Sexual maturation of female house mice: Social inhibition. Develop. Psychobiol. 7, 257-265.

Engen, T. (1974). Method and theory in the study of odor preferences. In J. W. Johnston, Jr., D. G. Moulton, and A. Turk (Eds.), "Advances in Chemoreception, Vol. II., Human Responses to Environmental Odors," pp. 121-141, New York: Academic Press.

Engen, T. and Lipsitt, L. P. (1965). Decrement and recovery of responses to olfactory stimuli in the human neonate. J. Comp. Physiol. Psychol. 59, 312-316.

Engen, T., Lipsitt, L. P., and Kaye, H. (1963). Olfactory responses and adaptation in the human neonate. J. Comp. Physiol. Psychol. 56, 73-77.

Fox, M. W. and Himwich, W. A. (1965). Olfactory imprinting: A measure of early learning in the neonate dog. Proc. Fed. Amer. Soc. Exp. Biol. 24, 522.

Fullerton, C. and Cowley, J. J. (1971). The differential effect of the presence of adult male and female mice on the growth and development of the young. J. Genet. Pschol. 119, 89-98.

Galef, B. G., Jr. and Henderson, P. W. (1972). Mother's milk: A determinant of the feeding preferences of weaning rat pups. J. Comp. Physiol. Psychol. 78, 213-219.

Gandelman, R. (1973). The development of cannibalism in male Rockland-Swiss mice and the influence of olfactory bulb removal. Develop. Psychobiol. 6, 159-164.

Gleason, K. K., and Reynierse, J. A. (1969). The behavioral significance of pheromones in vertebrates. Psychol. Bull. 71, 58-73.

Gregory, E. H. (1974). "Development of Olfactory Guided Behavior in the Golden Hamster." Paper presented at Society for Neuroscience, St. Louis.

Gregory, E. H. and Pfaff, D. W. (1971). Development of olfactory-guided behavior in infant rats. Physiol. Behav. 6, 573-576.

Hara, T. J., Ueda, K., and Gorbman, A. (1965). Electroencephalograph studies of homing salmon. Science $149,884-885$. 
Harlow, H. F. (1962). The heterosexual affectional system in monkeys. Amer. Psychol. 17, 1-9.

Harlow, H. F. (1965). Sexual behavior in the rhesus monkey. In F. A. Beach (Ed.), "Sex and Behavior," pp. 234-265. New York: John Wiley.

Hasler, A. D. and Wisby, W. J. (1950). Use of fish for the olfactory assay of pollutants (phenols) in water. Trans. Amer. Fish. Soc. 79, 64-70.

Hasler, A. D. and Wisby, W. J. (1951). Discrimination of stream odors by fishes and its relation to parent stream behavior. Amer. Natur. 85, 223-238.

Heimer, L. and Larsson, K. (1967). Mating behavior of male rats after olfactory bulb lesions. Physiol. Behav. 2, 207-209.

Hudgens, G. A., Denenberg, V. H., and Zarrow, M. X. (1968). Mice reared with rats: Effects of preweaning and postweaning social interactions upon adult behaviour. Behaviour 30, 259-274.

Idler, D. R., McBride, J、R., Jonas, R. E. E., and Tomlinson, N. (1961). Olfactory perception in migrating salmon. II. Studies on a laboratory bioassay for homestream water and mammalian repellent. Can. J. Biochem. Physiol. 39, 1575-1584.

Johnson, R. P. (1973). Scent marking in mammals. Anim. Behav. 21, 521-535.

Kalkowski, W. (1967). Olfactory bases of social orientation in the white mouse. Folia Biol. (Krakow) 15, 69-87.

Kalogerakis, M. G. (1963). The role of olfaction in sexual development. Psychosom. Med. $25,420-432$.

Kaplan, J. and Russell, M. (1974). Olfactory recognition in the infant squirrel monkey. Develop. Psychobiol. 7, 15-19.

Kennedy, J. M. and Brown, K. (1970). Effects of male odor during infancy on the maturation, behavior, and reproduction of female mice. Develop. Psychobiol. 3, 179-189.

Kling, A. (1964). Effects of rhinencephalic lesions on endocrine and somatic development in the rat. Amer. J. Physiol. 206, 1395-1400.

Kovach, J. D., and Kling, A. (1967). Mechanisms of neonate sucking behaviour in the kitten. Animal Behav. 15, 91-101.

Le Magnen, J. and Tallon, S. (1968). Preference alimentaire du jeune rat induite par l'allaitement maternel. C. R. Soc. Biol. (Paris) 162, 387-390.

Leon, M. (1974). Maternal pheromone. Physiol. Behav. 13, 441-453.

Leon, M. and Moltz, H. (1971). Maternal pheromone: Discrimination by pre-weanling albino rats. Physiol. Behav. 7, 265-267.

Leon, M. and Moltz, H. (1972). The development of the pheromonal bond in the albino rat. Physiol. Behav. 8, 683-686.

Leon, M. and Moltz, H. (1973). Endocrine control of the maternal pheromone in the postpartum female rat. Physiol. Behav. 10, 65-67.

Leonard, C. M. (1972). Effects of neonatal (Day 10) olfactory bulb lesions on social behavior of female golden hamsters (Mesocricetus auratus). J. Comp. Physiol. Psychol. 80, 208-215.

Leonard, C. M. (1974). Thermotaxis in golden hamster pups. J. Comp. Physiol. Psychol. $86,458-469$.

Lipsitt, L. P., Engen, T., and Kaye, H. (1963). Developmental changes in the olfactory threshold of the neonate. Child Develop. 34, 371-376.

Madison, D. M., Scholz, A. T., Cooper, J. C., Horrall, R. M., Hasler, A. D., and Dizon, A. E. (1973). Olfactory hypotheses and salmon migration: A synopsis of recent findings. Fish. Res. Board Can. Tech. Rep. 414, 1-35.

Mainardi, D., Marsan, M., and Pasquali, A. (1965). Causation of sexual preferences of the house mouse. The behaviour of mice reared by parents whose odour was artificially altered. Atti Soc. Ital. Sci. Nat. e Mus. Civico di Storea Nat. Milano 104, 325-338. 
Marr, J. N. and Gardner, L. E., Jr. (1965). Early olfactory experience and later social behavior in the rat: Preference, sexual responsiveness, and care of young. $J$. Genet. Psychol. 107, 167-174.

Marr, J. N. and Lilliston, L. G. (1969). Social attachment in rats by odor and age. Behaviour 33, 277-282.

Mayr, E. (1974). Behavior programs and evolutionary strategies. Amer. Sci. 62, 650-659.

Müller-Schwarze, D. and Muller-Schwarze, C. (1971). Olfactory imprinting in a precocial mammal. Nature (London) 229, 55-56.

Murphy, M. R. and Schneider, G. E. (1970). Olfactory bulb removal eliminates mating behavior in male golden hamster. Science 167, 302-304.

Mykytowycz, R. and Ward, M. M. (1971). Some reactions of nestlings of the wild rabbit,

Oryctolagus cuniculus (L.), when exposed to natural rabbit odors. Forma. Funct. 4, 137-148.

Nordeng, H. (1971). Is the local orientation of anadromous fishes determined by pheromones? Naiure (London) 233, 411-413.

Nyakas, C. and Endroczi, E. (1970). Olfaction guided approaching behaviour of infantile rats to the mother in maze box. Acta. Physiol. Acad. Sci. Hung. 38, 59-65.

Orbach, J. and Kling, A. (1966). Effect of sensory deprivation on onset of puberty, mating, fertility and gonadal weights in rats. Brain Res. 3, 141-149.

Oshima, K., Hahn, W. E., and Gorbman, A. (1969). Olfactory discrimination of natural waters by salmon. J. Fish. Res. Bd. Can. 26, 2111-2121.

Pfeiffer, W. (1963). Alarm substances. Experientia 19, 113-123.

Pfeiffer, W. (1974). Pheromones in fish and amphibia. In M. C. Birch (Ed.), "Frontiers of Biology, Vol. 32, Pheromones," pp. 269-296. New York: American Elsevier Publishing.

Pollak, E. I. and Sachs, B. D. (1975). Male copulatory behavior and female maternal behavior in neonatally bulbectomized rats. Physiol. Behav. 14, 337-343.

Porter, R. H. and Etscorn, F. (1974). Olfactory imprinting resulting from brief exposure in Acomys cahirinus. Nature (London) 250, 732-733.

Porter, R. H., Fullerton, C., and Berryman, J. C. (1973). Guinea pig maternal-young attachment behaviour. Z. Tierpsychol. 32, 489-495.

Powers, J. B. and Winans, S. S. (1973). Sexual behavior in peripherally anosmic male hamsters. Physiol. Behav. 10, 361-368.

Powers, J. B. and Winans, S. S. (1975). Vomeronasal organ: Critical role in mediating sexual behavior of the male hamster. Science 187, 961-963.

Quadagno, D. M. and Banks, E. M. (1970). The effect of reciprocal cross fostering on the behaviour of two species of rodents, Mus musculus and Baiomys taylori ater. Anim. Behav. 18, 379-390.

Rosenblatt, J. S. (1972). Learning in newborn kittens. Sci. Amer. 227, 18-25.

Rosenblatt, J. S., Turkewitz, G., and Schneirla, T. C. (1969). Development of home orientation in newly born kittens. Trans. N.Y. Acad. Sci. 31, 231-250.

Rouger, Y., Tobach, E., and Schneirla, T. C. (1967). "Development of Olfactory Function in the Rat Pup." Paper given at the Animal Behavior Society meeting at the AAAS meetings, New York.

Rovee, C. K. (1969). Psychophysical scaling of olfactory response to the aliphatic alcohols in human neonates. J. Exp. Child Psychol. 7, 245-254.

Rovee, C. K. (1972). Olfactory cross-adaptation and facilitation in human neonates. $J$. Exp. Child Psychol. 13, 368-381.

Sato, N., Haller, E. W., Powell, R. D., and Henkin, R. I. (1974). Sexual maturation in bulbectomized female rats. J. Reprod. Fertil. 36, 301-309.

Scalia, F. and Winans, S. S. (1975). The differential projection of the olfactory bulb and accessory olfactory bulb in mammals. J. Comp. Neurol. 161, 31-56. 
Schapiro, S. and Salas, M. (1970). Behavioral response of infant rats to maternal odor. Physiol. Behav. 5, 815-817.

Schönfelder, J. and Schwartze, P. (1971). Beiträge zur Steuerung der Bursttätigkeit des Bulbus olfactorius. Act. Biol. Med. German. 27, 103-110.

Schultz, E. F. and Tapp, J. T. (1973). Olfactory control of behavior in rodents. Psychol. Bull. 79, 21-44.

Selander, R. K. and Giller, D. R. (1961). Analysis of sympatry of great-tailed and boat-tailed grackles. Condor 63,29-86.

Self, P. A., Horowitz, F. D., and Paden, L. Y. (1972). Olfaction in newborn infants. Develop. Psychol. 7, 349-363.

Singh, P. J. and Tobach, E. (1972). "Effects of Olfactory Bulbectomy on Nursing Behavior in the Wistar (DAB) Rat Pup." Society for Neuroscience, Houston, Texas.

Singh, P. J. and Tobach, E. (1975). Olfactory bulbectomy and nursing behaviour in rat pups (Wistar DAB). Devel. Psychobiol. 8, 151-164.

Small, W. S. (1899). Notes on the psychic development of the young white rat. Amer. $J$. Psychol. 11, 80-100.

Solomon, D. J. (1973). Evidence for pheromone-influenced homing by migrating Atlantic salmon, Salmo salar (L.) Nature (London) 244, 231-232.

Stark, B. and Hazlett, B. A. (1972). Effects of olfactory experience on aggression in Mus musculus and Peromyscus maniculatus. Behav. Biol. 7, 265-269.

Supak, T. D., Macrides, F., and Chorover, S. L. (1971). The bait-shyness effect extended to olfactory discrimination. Commun. Behav. Biol. 5, 321-324.

Sutterlin, A. M. and Gray, R. (1973). Chemical basis for homing of Atlantic salmon (Salmo salar) to a hatchery. J. Fish. Res. Bd. Can. 30, 985-989.

Thunberg, B. E. (1971). Olfaction in parent stream selection by the alewife (Alosa pseudoharengus). Anim. Behav. 19, 217-225.

Tobach, E., Rouger, Y., and Schneirla, T. C. (1967). Development of olfactory function in the rat pup. Amer. Zool. 7, 792-793.

Ueda, K., Hara, T. J., and Gorbman, A. (1967). Electroencephalographic studies on olfactory discrimination in adult spawning salmon. Comp. Biochem. Physiol. 21, 133-143.

Valenstein, E. S., Cox, V. C., and Kakolewski, J. W. (1969). Sex differences in hyperphagia and body weight following hypothalamic damage. An. N.Y. Acad. Sci. 157, 1030-1048.

Valenstein, E. S., Kakolewski, J. W., and Cox, V. C. (1967). Sex differences in taste preference for glucose and saccharin solutions. Science 156, 942-943.

Valenstein, E. S., Riss, W., and Young, W. C. (1954). Sex drive in genetically heterogeneous and highly inbred strains of male guinea pigs. J. Comp. Physiol. Psychol. 47, 162-165.

Vandenbergh, J. G. (1967). Effect of the presence of a male on the sexual maturation of female mice. Endocrinology 81, 345-349.

Vandenbergh, J. G. (1969). Male odor accelerates female sexual maturation in mice. Endocrinology 84, 658-660.

Vandenbergh, J. G. (1974). Social determinants of the onset of puberty in rodents. $J$. Sex Res. 10, 181-193.

Vandenbergh, J. G., Drickamer, L. C., and Colby, D. R. (1972). Social and dietary factors in the sexual maturation of female mice. J. Reprod. Fertil. 28, 397-405.

Walker, T. J. and Hasler, A. D. (1949). Detection and discrimination of odors of aquatic plants by the bluntnose Minnow (Hyborhynchus notatus). Physiol. Zool. 22, $45-63$. 
Wallace, P., Thiessen, D. D., and Issacks, N. (1975). "Scent Marking Behavior in the Female Mongolian Gerbil: Hormonal Controls and Functional Significance." Tape-slide presentation at the Winter Conference on Brain Research, Steamboat Springs, Colorado.

Welker, W. R. (1964). Analysis of sniffing of the albino rat. Behaviour 22, 223-244.

Wilhelmsson, M. and Larsson, K. (1973). The development of sexual behavior in anosmic male rats reared under various social conditions. Physiol. Behav. 11, 227-232.

Wilson, E. O. (1972). Animal communication. Sci. Amer. 227, 53-60.

Wilson, S. (1973). The development of social behaviour in the vole (Microtus agrestis). Zool. J. Linn. Soc. 52, 45-62.

Winans, S. S. and Powers, J. B. (1974). Neonatal and two-stage olfactory bulbectomy: Effects on male hamster sexual behavior. Behav. Biol. 10, 461-471.

Winans, S. S., and Scalia, F. (1970). Amygdaloid nucleus: New afferent input from the vomeronasal organ. Science 170, 330-332.

Zarrow, M. X., Christenson, C. M., and Eleftheriou, B. E. (1971). Strain differences in the ovulatory response of immature mice to PMS and to the pheromonal facilitation of PMS-induced ovulation. Biol. Reprod. 4, 52-56.

Zarrow, M. X., Estes, S. A., Denenberg, V. H., and Clark, J. H. (1970). Pheromonal facilitation of ovulation in the immature mouse. J. Reprod. Fertil. 23, 357-360. 